\title{
An Analysis of Comparative Advantage and Intra-North American Free Trade Agreement (NAFTA) Trade Performance
}

\author{
Macleans Mzumara $^{1}$, Anna Chingarande ${ }^{1} \&$ Roseline Karambakuwa ${ }^{1}$ \\ ${ }^{1}$ Department of Economics, Bindura University of Science Education, Bindura, Zimbabwe \\ Correspondence: Macleans Mzumara, Department of Economics, Bindura University of Science Education, \\ P/Bag 1020, Bindura, Zimbabwe. Tel: 263-712-735-723. E-mail: macmzumara@yahoo.com
}

Received: July 11, 2012 Accepted: October 19, 2012 Online Published: October 30, 2012

doi:10.5539/jsd.v5n11p103 URL: http://dx.doi.org/10.5539/jsd.v5n11p103

\begin{abstract}
The authors analysed comparative advantage of Canada, Mexico and the United States in the context of the North American Free Trade Agreement (NAFTA). The authors found that there is empirical evidence as expected that the United States of America has a large number of products in which it has a comparative advantage in, followed by Canada. Mexico is the least competitive with fewer products compared to the United States of America and Canada. The authors have also concluded that having comparative advantage is not synonymous with trade performance in intra-regional trade as Mexico tends to benefit much more in spite of having a very few products in which it has comparative advantage as demonstrated by huge trade surpluses over Canada and the United States.
\end{abstract}

Keywords: comparative advantage, revealed comparative advantage, intra-NAFTA trade performance, International trade

\section{Introduction}

There are many regional groupings around the world. Although free trade has not been attained globally, regional trading blocs seem to provide a mechanism of free trade. These regional groupings to a greater extent have removed trade restrictions within their members but remain with high walls of restrictions imposed on third parties (Institute for International Economics, 2012). The international participation in Free Trade Zones has significantly grown especially in the second half of the $20^{\text {th }}$ century (Global Economics, 2012). This has resulted in many regional economic groupings which include: European Union (EU), Caribbean Common Market (CARICOM), Central American Common Market (CACM), Latin America Integration Association (LAIA), Association of South East Asia Nations (ASEAN), Mercosur, Southern Africa Customs Union (SACU), Common Market for Eastern and Southern Africa (COMESA), East African Community (EAC), Economic Community of Central African States (ECCAS), Economic Community of West African States (ECOWAS), Arab Maghreb Union (AMU), Community of Sahel -Saharan States (CEN-SAD), Inter-governmental Authority for Development Community (IGAD) and Southern African Development Community (SADC) (Claiming Human Rights, 2012; FAO, 2012).

The largest and most successful of the regional groupingis the European Union (EU). It has achieved the highest level of integration than any other groupings by establishing the European Monetary Union (EMU). The EU constitute a very small portion of world population accounting for $6.3 \%$ but command $20 \%$ of world GDP and more than $40 \%$ of the world exports (Global Economics, 2012). The EU and its member states have organized huge amount of resources for economic recovery (European Union, 2012). However, in Africa despite the mushrooming of regional economic integration groupings, Sub Saharan economic growth achievement remains very poor (World Bank, 2012). There are mixed results when regional groupings are evaluated. The most powerful nation on the planet, the United States of America, saw it fit to join two other nations namely Canada and Mexico to form the North American Free Trade Agreement (NAFTA). The authors intend to investigate whether there is evidence of comparative advantage in NAFTA and evaluate the group's trade performance. Although, there may be some studies which have been done in the past on NAFTA, the authors intend to focus on recent data from 2007 to 2010 in establishing whether NAFTA has comparative advantage and analyse its trade performance. According to Shinyekwa and Othieno (2011) some products do not obviously maintain 
revealed comparative advantage (RCA) beyond four yearst. This provides a strong justification to carry out this investigation.

The concept of establishing the North American Free Trade Agreement (NAFTA) began in 1979 during the United States of America's President Ronald Regan election campaign. He saw the existence of NAFTA as a way of encouraging economic growth through free movement of goods and services between the United States of America, Canada and Mexico. However, the idea became a reality years later after President Ronald Regan left office (Ford, 2012). The North American Free Trade Agreement (NAFTA) which comprises the United States, Canada and Mexico was launched on January 1, 1994 during the reign of President Bill Clinton. NAFTA is the successor of Canada - United States of America Free Trade Agreement which was operational from 1989 (Ford, 2012; USDA, 2012). OAS-SEDI-DEDIT (2012) outline the objectives of NAFTA as provided in Chapter one Article 102 as follows: eliminate restrictions to trade and encourage the cross-border movement of goods and services in member states territories; encourage conditions for fair competition within the free trade area; increasing investment opportunities in the territories of member state; enabling effective protection and enforcement of the intellectual property rights in each member's territory; providing effective procedures for implementing and application of the agreement for joint administration and the resolution of disputes; and create a framework for future bilateral, regional and multilateral cooperation to increase gains arising from the agreement.

The agreement provides a mechanism of dispute settlement relating to investment. It provides assurances for equal treatment among investors in member state's territories. It provides the following mechanisms for arbitration: the World Bank's International Centre for the Settlement of Investment Disputes (ICSID); ICSID's additional facility rules; and the rules of the United Nations Commission for International Trade Law (NAFTA, 2012). Chapter 19, Article 1904 provides a mechanism for judicial review by local Courts of final determination in antidumping and countervailing duty disputes by independent panels. A Panel is established if the aggrieved industry files the request with the NAFTA Secretariat. Chapter 19 Annex 1904, 13 spells out that although a Panel's decision is binding a review of binational Panel can be initiated by any NAFTA government. Further, Chapter 19, Article 1905 provides a mechanism for protecting the Panel review system. In pursuance of this provision, a three member special committee may be established to review allegations made by aggrieved party that another party's domestic law has interfered with the proper administration of the Panel system. In further pursuant of this, NAFTA has put in place several rosters of individuals from which panellists are appointed to settle disputes based on their good character, high standards and reputation based on their objectivity, reliability, sound judgement and with their knowledge of international law (NAFTA, 2012). Chapter 20 provides mechanisms for interpretation or application of NAFTA. It further provides a scientific review boards which may be selected by the Panel with consultation with the aggrieved party (NAFTA, 2012).

Mexico and Canada came up with a separate bilateral NAFTA agreement on market access for farm products. This bilateral agreement removed most tariffs with immediate effect or over a timeframe of 5, 10 or 15 years. Tariffs between the two nations which affected trade in dairy, poultry, eggs and sugar were maintained. The agricultural provision of the United States - Canada Free Trade Agreement which was operational from 1989 was in fact incorporated into NAFTA provisions. All tariffs which were restricting agricultural trade between the United States of America and Canada were removed by January 1, 1998 except for a few products covered by tariff-rate and quotas (USDA, 2012). According to Zahniser and Crago (2009) in 2008, the last hurdles on trade restrictions of the triangular agreement of the United States of America - Canada - Mexico were removed. This concluded the roadmap which took 14 years to remove numerous restrictions to intra-NAFTA agricultural trade. During the time of implementation of the agreement, the agricultural sectors of Mexico, the United States of America and Canada have become more integrated. The United States of America's feedstuffs have helped to increase production of meat production in Mexico. On the other hand, Mexican and Canadian produce have also helped the United States of America fruit industry's growth.

\section{Literatures on Free Trade Zones and Comparative Advantage}

Regional trade arrangements have the ability to influence demand of non-members products negatively, leading to decline in prices. Further stiff competition in the free trade area (FTA) causes firms outside the free trade area to reduce their prices in order for them to maintain exports in the FTA. The benefit for the FTA is improvement in the terms of trade (World Bank, 2012). The conventional economic approach to regional trade integration assumes that there is perfect competition in markets. It is further interested with the implication of establishing a regional grouping for the purpose of resource allocation (FAO, 2012). According to the World Bank (2012) free trade zones provide increased returns and increased competition. Another benefit is market enlargement which 
removes disadvantages created by trade-offs. Regional trade arrangements also attract foreign direct investment (FDI) originating from non-members. This move leads to market enlargement and supply rationalization.

The concept of revealed comparative advantage (RCA) is premised in the international trade theory (Ferto \& Hubbard, 2000). The Ricardian theory traces comparative advantage to differences in advancement of technology across countries. On the other hand the Hecksher - Ohlin theory attributes comparative advantage from cost differences based on each country's factor scarcity (Khatibi, 2008). The classical theory of the comparative advantage emphasizes that benefits from exchange optimize welfare and that trade without restrictions would make the world better and prosperous. The theories do not attribute the same way what determines comparative advantage. Each theory seems to emphasize on some aspects. The Ricardian theory attributes comparative from the differences in costs and technological advancement whereas Heckscher-Ohlin-Samuelson theory focuses on factor prices differential. The Neo-Factor-proportion theory emphasizes on efficiency (productivity) of the factors. The technology gap and product cycle theory emphasizes on technological innovations as a source of comparative advantage (Bender \& Li, 2002).

According to Widgren (2005) Heckscher -Ohlin theorem attributes comparative advantage from a factor endowment. This is shared by Mzumara (2006) who also attributes to differences in international costs due to factor endowments. Widgren (2005) and Mzumara (2006) both make emphasis on factor endowments as determinants of comparative advantage. Their explanations differ from that of Khatibi (2008) who places the source from factor endowment scarcity. However, it is not the scarcity of endowment which gives rise to comparative advantage but the abundance of a particular factor. Thus according to Widgren (2005) a nation will export products which use the abundant factor intensively and import those products which use scarce factor intensively. Mzumara (2006) asserts that a country with an abundant factor such as labour will export the products which use its abundant factor most intensively and will import those products which use its scarce factor (in this case capital) less intensively. Accordingly, Mzumara (2006) stipulates there is going to be a specialization in labour intensive products for this country. As such, it is not the scarce factor which determines comparative advantage as Khatibi (2008) puts it rather relative scarcity would determine comparative disadvantage (instead of comparative advantage).

According to Ferto and Hubbard (2000) RCA index is a useful tool in determining whether a particular country indeed has a comparative advantage, although, it shades little light on the degree of comparative advantage. The RCA measure uses observable trade balance to conclude the relative sectoral competiveness a given sector demonstrates competiveness when it produces efficiently. RCA indexes measure a nation's comparative advantage and this is done in a normal way. It is simply a ratio of ratios which demonstrate relative trade shares (Richardson \& Zhang, 2001). The RCA measure uses the trend of trade balances to demonstrate relative sectoral competiveness. Sectors that demonstrate international competiveness at producing products for the external market whereas sectors that end up only importing inhibit lack of competiveness The RCA is therefore most acceptable measure as it is not determined by restrictive assumptions which are not valid practically (Mutambatsere, 2007). According to Donges (1982) RCA indices do not measure efficiency in the sense that they only define trade trend or pattern which have occurred but comes short in pointing optimality off the pattern. Further the RCA does not show where exactly the comparative advantage originates, therefore may not be revealed based only on the differences between countries such as those brought by measures that offer protection, transport costs, taste and traditional affiliation.

Balance et al. (1987) call for some statistical tests to deal with the issue of consistency of the various RCA indices in demonstrating comparative advantage. They provide two interpretations. The first one being that RCA assists in ranking of goods by degree of comparative advantage. Secondly the RCA measure shows a binary type dividing line of goods which have comparative advantage on one hand and those which do not have on the other. They then refer those as cardinal, ordinal and dichotomous hence they call for a test of consistency for each. The consistency test of the indices as a form of cardinal measure of comparative advantage depends on the association coefficient between the indices involved in each of the seven years used (Ferto \& Hubbard, 2002).

Vollarth (1991) came up with three alternative specifications of the revealed comparative advantage. The first one is relative trade advantage (RTA) which takes into consideration of both exports and imports. It is computed as the difference between relative export advantage (RXA) which is then equated to the RCA index of Balassa corresponding to relative import advantage (RMA) such that:

RTA $=$ RXA - RMA

where

$\mathrm{RXA}=\mathrm{B}$ (Balassa) 
And

$\operatorname{RMA}=\left(\mathrm{m}_{\mathrm{ij}} / \mathrm{m}_{\mathrm{it}}\right) /\left(\mathrm{m}_{\mathrm{nj}} / \mathrm{m}_{\mathrm{nt}}\right)$

Where

$\mathrm{m}_{\mathrm{ij}}$ denoting imports in country I of product category of $\mathrm{j}$

$\mathrm{m}_{\mathrm{it}}$ denoting imports of country I of set of commodities $\mathrm{t}$

Therefore

$\operatorname{RTA}=\left[\left(\mathrm{X}_{\mathrm{ij}} / \mathrm{X}_{\mathrm{it})} / \mathrm{X}_{\mathrm{nj}} / \mathrm{X}_{\mathrm{nt}}\right)\right]-\left[\left(\mathrm{m}_{\mathrm{ij}} / \mathrm{m}_{\mathrm{it}} /\left(\mathrm{m}_{\mathrm{nj}} / \mathrm{m}_{\mathrm{nt})]}\right.\right.\right.$

Where

$\mathrm{X}_{\mathrm{ij}} \quad$ denoting exports of country $\mathrm{i}$ of product category $\mathrm{j}$

$X_{i t}$ denoting exports of country $i$ of set of commodities $t$

$X_{n j}$ denoting exports of set of countries, $n$ of product category ${ }_{j}$

$X_{n t}$ denoting exports of set of countries, $n$ of set of commodities, $t$

$m_{i j}$ denoting imports of country $i$ of product category $j$

$\mathrm{m}_{\mathrm{it})}$ denoting imports of country $\mathrm{i}$ iof set of commodities, $\mathrm{t}$

$m_{n j}$ denoting imports of set of countries, $n$ of product category $j$

$\mathrm{m}_{\mathrm{nt}}$ denoting imports of set of counties, $\mathrm{n}$ of set of commodities, $\mathrm{t}$

The second measure is basically a logarithm of the RTA such that In RXA and hence the third specification is revealed competiveness (RC) such that

Revealed Competiveness (RC) = In RXA - In RMA

The benefit of showing the last two measures given in logarithm is their being asymmetric thus all Vollrath's measure tends to be positive and are summarized as RTA, In RXA and RC which is reveal comparative advantage alternatively competitive advantage (Ferto \& Hubbard, 2000). The difference between Balassa's B and Vollrath's RXA is that the RXA removes country and product double-counting a weakness of the Balassa's index. The RXA further considers all tradable products and all nations instead of subsets hence is more international (Ferto \& Hubbard, 2000).

Serin and Civan (2008) provide another measure besides the RCA. They call it Comparative Export Advantage (CEP) index. It is basically a modified Balassa's measure. It focuses on measuring export specialization of a nation for specific groups of goods and applies the following formula:

$\mathrm{CEP}=\operatorname{In}\left(\mathrm{X}_{\mathrm{iB}} / \mathrm{X}_{\mathrm{B}}\right) /\left(\mathrm{X}_{\mathrm{iA}} / \mathrm{X}_{\mathrm{A}}\right)$

with

$\mathrm{X}_{\mathrm{iB}}$ denoting country B's exports of good $\mathrm{i}$

$\mathrm{X}_{\mathrm{B}}$ denoting B's total exports

$\mathrm{X}_{\mathrm{iA}}$ denoting total world exports of good $\mathrm{i}$

$\mathrm{X}_{\mathrm{A}}$ denoting total world exports of all goods

Therefore an index value of B greater than the index value of country's $n$ shows relative comparative advantage of country B against $n$.

Utkulu and Seymen (2004) indicate that there are four different measures which can be used to measure competiveness. These are: revealed comparative advantage (RCA); comparative export comparative (CEP); trade overlap (TO); and export similarity (ES) indices. The different measures so far advanced seem to heed the call of Balassa (1965) that some factors cannot be quantified. According to Bebek (2011), Balassa focused on comparative advantage that it manifests itself in various factors of which cannot be quantified (in some) and neither observed. The challenge which was put forward was whether observed trade pattern could lead to providing empirical evidence for determinants of overall trade pattern. 


\subsection{Empirical Evidence of Comparative Advantage}

Yeats (1997) using RCA and statistics found that there is no evidence of Mercosur of having comparative advantage in its products. The findings further established that Mercosur's own trade barriers influences trade changes. Mirzaei, Yazdani and Gharahdagh (2004) found that Iran has no comparative advantage in exporting eggs to the Middle East. Utkula and Seymen (2004) found that there is a possible negative trade creation effect for Turkey in the event of joining the EU. Trade diversion effects are not significant. However, the study used two - digit SIT REV 3 data which is not disaggregative. Mutambatsere (2007) found that half of SADC member states do not have comparative advantage in the production of maize. Only South Africa, Tanzania and Malawi had comparative advantage. Hansen and Meyers (2012) found that within NAFTA grouping, the United States of America's price shocks also affect Mexico. However the study was limited to agricultural products. Odhiambo (2010) found that asymmetry policy did not have a significant effect in reducing imbalance in competiveness between Uganda and Kenya. That Kenya was more competitive than Uganda in the context of the East African Community. Shinyekwa and Othieno (2011) found that Uganda has comparative advantage in very limited range of products and do not maintain the RCA beyond four years. Mzumara (2011a) based on RCA concluded that Zimbabwe which is a member of COMESA and SADC is competitive and has comparative advantage in production of a wide range of products. Mzumara (2011b) found Mozambique which is a member of SADC to have comparative advantage in 222 products which it produces. Mzumara (2012) using Harmonised 6-digit data level found that Botswana is not a mono-diamond economy and has a comparative advantage in 244 products.

\subsection{Intra-Regional Measure of Trade Perfomance}

Yeats (1997) raised a concern regarding various regional trade arrangements (RTA). The major concern is whether the RTAs' discriminatory trade barriers promote inefficiency through promoting and protecting high cost producers within members at the expense of low cost producers outside the RTAs. The major problem of providing appropriate evaluation is the fact that there is no consensus from researchers to standardise procedures of providing empirical research on RTAs. This lack of common procedure of dealing with evaluation is creating a problem. Yeats (1997) further advocates the use of a new index in analysing a single aspect of the RTA being its static trade effects. Its advantage is that it investigates changes in the regional pattern of exports and demonstrates how data can be used in connection with the RCA indices in order to single out "inefficiencies" in trade patterns. Edwards and Lawrence (2006) indicate that the most disappointing thing is the fact that trade performance itself is not mentioned as a huge limitation on growth. There have been concerns which have been voiced about the instability of exchange rate, investment and promotion strategies aimed at export diversification but not much on trade performance. Trade performance seems to be explicit with the above concerns. Kowalski (2011) believes that trade performance is based on comparative advantage. In that the comparative advantage theory focuses on the relative differences in productivity between nations that bringin international trade and its resultant benefits. Thus the bigger the difference in a particular source of comparative advantage, the bigger will be the portion of benefit across nations. Further, Kowalski (2011) asserts that comparative advantage moves in tandem with policies and institutions although it does not advocate nations to influence it. The results however confirmed that it is the difference in national policy settings and policy performance which lead to differences in productivity among nations and eventually lead to increase in benefits arising from international trade. Thus some differences may be due to the stage at which a nation may be in terms of economic development. It may also be due to strategic policy choice adopted by a particular country for example, it may decide to invest more in human capital than investing in physical capital. However such a move should not prevent nations which want to be at the same level like others in terms of performance but rather that they focus on trade bringing in benefits even at the beginning of such efforts of catching up. The conclusion Kowalski (2011) makes is that trade liberalization and comparative advantage led specialization is not a limitation to economic development process rather it drives it.

\section{Methodology}

In spite of some weaknesses of Balassa's RCA, it remains the most useful measure in international trade. According to Deardorff (2010) the RCA remains valid in revealing true comparative advantage. It is also useful as a guide in trade policy making. Richardson and Zhang (2001) used the RCA in analysing patterns across time and sectors and the United States trading partners. Karakaya and Ozgen (2002) used the RCA index approach to investigate the potential trade creation and diversion effects of the economic integration for Turkey with the European Union. Kalaba and Tseudo (2008) used the RCA in assessing the implementation of the Southern African Development Community (SADC) trade protocol and intra-SADC trade performance. Mzumara (2011a; 
2011 ; 2012) used the RCA in assessing competiveness of Zimbabwe, performance of Mozambique from Marxist-Lennnist policies to market based policies and an evaluation of whether Botswana is a mono diamond economy or not. This paper has opted therefore to employ the Balassa (1965) RCA in the form of:

$$
R C A=\left(\frac{X_{i, j}}{X_{W, j}}\right) /\left(\frac{X_{i, t o t}}{X_{W, t o t}}\right)
$$

With:

$\mathrm{X}_{\mathrm{i}, \mathrm{j}}$ denoting country i's exports of product $\mathrm{j}$;

$X_{i, t o t}$ denoting country i's total exports;

$\mathrm{X}_{\mathrm{w}, \mathrm{j}}$ denoting the world's (all countries) export of product $\mathrm{j}$; and

$\mathrm{X}_{\mathrm{w}, \text { tot }}$ denoting total exports in the world.

An RCA of equal and greater than 1 demonstrates that the country has revealed comparative advantage, in other words, the country is relatively specialised in producing and exporting the product line under consideration. An RCA closer to 0 demonstrates that the country has a lower revealed comparative advantage and is not specialised in the product line (Balassa, 1965; Krugell \& Matthee, 2009). The authors have used trade data obtained from International Trade Centre (ITC)'s Trademap based in Geneva, Switzerland to compute RCA indices for Canada, Mexico and United States of America. ITC has a database for each and every country's imports and exports from 2001 upwards. All countries of the world report their trade data to ITC. Data on exports and imports for each and every country up 2000 is stored in the database of the United Nations Comtrade (UNCOMTRADE) (ITC, 2012). Harmonized 6-digit export data the most disaggregate has been used to compute each country's RCA for 2007 to 2010 then obtained an average RCA. 2007 to 2010 data has been used because it is the most recent data for most of the countries. The RCA measures comparative advantage and competitiveness (Kowalski, 2011).

Further the authors have used trade statistics obtained from the same source as above to compute growth rates used to analyse trade performance in respect of intra-NAFTA trade.

\section{The Results}

The United States of America has revealed comparative advantage equal or greater than 1 in 1791 product codes.

Table1 shows top 20 products with the highest RCA.

Table 1. Top 20 products based on RCA index in the United States of America

\begin{tabular}{ccccccc}
\hline Product code & Product description & RCA 2007 & RCA 2008 & RCA 2009 & RCA 2010 & Average RCA \\
\hline 300331 & Insulin & 10.9 & 11.6 & 10.5 & 9.7 & 10.7 \\
930111 & Artillery weapon & 7.7 & 10.1 & 1.4 & 10.5 & 7.4 \\
230330 & Brewing dregs & 9.6 & 10.5 & 9.6 & 10.1 & 10 \\
880521 & Air combat simulators & 9.1 & 8.2 & 10.3 & 9.9 & 9.4 \\
100610 & Flour & 9.7 & 10.4 & 8.4 & 8.6 & 9.3 \\
080211 & Almonds & 9 & 9.4 & 8.6 & 10.4 & 9.3 \\
901720 & Drawing instruments & 9.1 & 8.9 & 8.8 & 8.5 & 8.8 \\
293292 & 1(1,3-Benzodioxol-5-y & 4.6 & 0 & 5 & 9.5 & 8.7 \\
370239 & Photo films & 8.6 & 9.6 & 8.6 & 7.3 & 8.5 \\
480452 & Paper & 8.6 & 9.4 & 8.1 & 7.3 & 8.4 \\
470419 & Chemical-wood pulp & 8.6 & 10.7 & 7 & 7.3 & 8.3 \\
100700 & Sorghum & 8.7 & 9 & 8.4 & 7.2 & 8.3 \\
370251 & Film colour $<16 \mathrm{~mm}$ & 6.8 & 7.4 & 8.8 & 9.2 & 8.1 \\
297424 & Ethinamate & 9.8 & 5.5 & 7.5 & 9.7 & 8.1 \\
080212 & Almonds fresh & 7.8 & 8.1 & 7.8 & 8.1 & 8 \\
391211 & Cellulose acetates & 7.6 & 8.3 & 7.8 & 8.1 & 8 \\
880510 & Aircraft launching & 7.1 & 7.4 & 8.5 & 8.4 & 7.9 \\
284019 & Disodium tetraborate & 7.5 & 8.2 & 7.7 & 7.3 & 7.7 \\
271311 & Petroleum coke & 5.9 & 8.1 & 8 & 8.3 & 7.6 \\
440831 & Veneer & 3.3 & 9 & 8.7 & 9.2 & 7.5 \\
\hline
\end{tabular}


Canada has revealed comparative advantage equal or greater than 1 in 814 product codes. Table 2 shows top 20 products with the highest RCA.

Table 2. Top 20 products based on RCA in Canada

\begin{tabular}{ccccccc}
\hline $\begin{array}{c}\text { Product } \\
\text { code }\end{array}$ & Product description & RCA & RCA & RCA & RCA & $\begin{array}{c}\text { Average } \\
\text { RCA }\end{array}$ \\
\hline 170220 & Maple sugar & 29.4 & 30.5 & 33.1 & 32.1 & 31.3 \\
441850 & Shingles of wood & 28.3 & 29.8 & 32.4 & 31.3 & 30.5 \\
100830 & Canary seed & 27.1 & 28.8 & 31.2 & 29 & 29 \\
030612 & Lobsters frozen & 23.9 & 27.1 & 29.7 & 30.5 & 27.8 \\
160530 & Lobsters prepared & 25 & 29 & 27.6 & 29 & 27.7 \\
282911 & Sodium chlorate & 22.2 & 25.8 & 34 & 28.5 & 27.6 \\
470500 & Semi-chemical wood pulp & 23.7 & 23.5 & 27.5 & 25.1 & 25.7 \\
880529 & Ground flying trainers & 20 & 21.3 & 31.8 & 27.9 & 25 \\
030542 & Herrings & 21.3 & 21.3 & 26.9 & 26.2 & 23.9 \\
841121 & Turbo-prop engines & 19.7 & 20.6 & 26.4 & 24.9 & 22.9 \\
710210 & Diamonds & 18.7 & 22.4 & 21.9 & 23.5 & 21.7 \\
100400 & Oats & 21.1 & 21 & 23.2 & 21.4 & 21.7 \\
810930 & Zirconium waste & 18.8 & 16.4 & 25.4 & 23.5 & 21 \\
071340 & Lentils dried & 16.4 & 20.9 & 23.9 & 22 & 20.8 \\
284510 & Heavy water & 22.2 & 13.6 & 21.5 & 23.2 & 20.1 \\
280200 & Sulphur & 14.3 & 24.9 & 19.6 & 21.3 & 20 \\
110319 & Cereal groats & 15.6 & 18.9 & 21.4 & 20.3 & 19.98 \\
252930 & Leucite & 17.1 & 16 & 19.8 & 21.3 & 18.6 \\
021091 & Meat \& edible meat offal of & & & & 25.2 & 6.4 \\
\hline
\end{tabular}

Mexico has revealed comparative advantage equal or greater than 1 in 749 product codes. Table 3 shows top 20 products with the highest RCA.

Table 3. Top 20 products based on RCA index in Mexico

\begin{tabular}{|c|c|c|c|c|c|c|}
\hline $\begin{array}{l}\text { Product } \\
\text { code }\end{array}$ & Product description & $\begin{array}{l}\text { RCA } \\
2007\end{array}$ & $\begin{array}{l}\text { RCA } \\
2008\end{array}$ & $\begin{array}{l}\text { RCA } \\
2009\end{array}$ & $\begin{array}{l}\text { RCA } \\
2010\end{array}$ & $\begin{array}{c}\text { Average } \\
\text { RCA }\end{array}$ \\
\hline 860691 & Railway cars, closed or open & 30 & 25.6 & 24.3 & 29.4 & 27.3 \\
\hline 811020 & Antimony waste and scrap & 25.1 & 18.9 & 20.7 & 30.5 & 23.3 \\
\hline 080440 & Avocados, fresh or dried & 23.3 & 23.7 & 23 & 20.3 & 22.5 \\
\hline 080720 & Papaws, fresh & 14.8 & 16 & 20.2 & 16.8 & 17 \\
\hline 900653 & Cameras for $35 \mathrm{~mm}$ roll films & 14.8 & 18.6 & 17.5 & 15.2 & 16.5 \\
\hline 030345 & Bluefin tunas & 2.5 & 9 & 29.2 & 23 & 15.9 \\
\hline 370293 & $\begin{array}{l}\text { Photo film in rolls width } 16-35 \mathrm{~mm}<30 \mathrm{~m} \\
\text { long }\end{array}$ & 16.4 & 18.4 & 14.7 & 13.2 & 15.7 \\
\hline 220890 & Alcoholic liqueurs & 15.7 & 15.5 & 14.9 & 14.8 & 15.2 \\
\hline 283692 & Strontium carbonate & 7.4 & 6.7 & 24.9 & 18 & 14.2 \\
\hline 370254 & $\begin{array}{l}\text { Film, colour photo rolls width } 16-35 \mathrm{~mm}< \\
30 \mathrm{~m} \text { long }\end{array}$ & 12.3 & 14.9 & 16.5 & 12.3 & 14 \\
\hline 870431 & $\begin{array}{c}\text { Spark ignition engine trucks weighing }< \\
\text { 5tonnes }\end{array}$ & 8.8 & 12.8 & 16.8 & 16.4 & 13.7 \\
\hline 281111 & Hydrogen fluoride & 13.7 & 11.2 & 15 & 12 & 13 \\
\hline 691090 & Ceramic bathroom kitchen sanitary items & 10.6 & 12 & 13.8 & 13.2 & 12.4 \\
\hline 080711 & Water melons, fresh & 10.7 & 11.9 & 14.9 & 11.6 & 12.2 \\
\hline 252922 & Fluospar $<97 \%$ calcium fluoride & 10.4 & 9.5 & 15.7 & 11.3 & 11.7 \\
\hline 291524 & Acetic anhydride & 8.7 & 9.1 & 15.1 & 11.7 & 11.2 \\
\hline 740329 & Copper alloys & 5.4 & 7 & 13.5 & 16.3 & 10.6 \\
\hline 283330 & Alums & 7.5 & 11 & 10.9 & 11.6 & 10.3 \\
\hline 070420 & Brussels sprouts & 13.1 & 15.2 & 11.5 & 11 & 10.2 \\
\hline 070920 & Asparagus & 8.4 & 7.5 & 10.3 & 11.7 & 9.5 \\
\hline
\end{tabular}




\section{Discussion and Analysis}

The United States of America has the largest number of product codes in which it has comparative advantage. It has comparative advantage in 1791 product lines. The number of products is more than double of those of Canada and also those of Mexico. However, in terms of average indices, the United States of America's has the highest average RCA in the production of insulin with average RCA of 10.7. This is lower than Canada's highest average index in production of sugar which has RCA of 31.3. In respect of Mexico, the product with the highest average index, railway car which has an RCA of 27.3 also exceeds the United States' highest average index. Although the United States of America specialization is at lower level in terms of the value of the RCA indices, it is competitive and has comparative advantage in large number of the products as well as in high value in terms of export potential and actual exports such as those from defence industries such as artillery weapons, aircraft launchers and air combat simulators. The top 20 products with the highest RCA in the United States of American are mainly high level manufactured products with high value addition and there are a few products of lower values such as sorghum, almonds (fresh) and flour. The product lines in which the three countries have comparative advantage are very different in each country except photo films which appear common in both the United States of America and in Mexico. The level of the number of the products in this regional grouping is such that it conforms to trade creation rather than trade diversion.

Canada is the second country in the triangular trading bloc in terms of the number of products the country has comparative advantage in. It has comparative advantage in 814 products. This is almost less than half the number of the United States of America's product lines. However, Canada has a slight advantage over Mexico. Canada has both high level manufacturing amongst its top 20 products with the highest RCA indices and fair level products without much value addition such as canary seeds and frozen lobsters. The indices are quitehigh compared to the United States of America with 19 of the products their indices ranging from 18.6 to 31.3 as opposed to the highest index for the United States of America being 10.7. Canada is highly specialized in those 814 products as demonstrated by very high RCAs greater than 1 .

Mexico appears to be the least in terms of the number of the products it has comparative advantage in the triangular trading bloc. It has 749 products in which it has comparative advantage in. This is 1042 products less than those in which the United States of America has comparative advantage in. This is also 65 products less than those in which Canada has comparative advantage. In Mexico there is a high level mixture of no value added products such as avocados, papaws bluefin tunas, water melons, Brussels sprouts, asparagus and copper alloys. The highest values of RCA are comparable to those of Canada but not comparable to those of the United States of America and amongst the top 20 products range from 9.5 to 27.3 and 19 of those top 20 products having above 10 .

These results are consistent with the findings of the earlier studies done by Mzumara (2011a, 2011b; 2012). However, results are not consistent with the findings of Yeats (1999), Mirzaei et al. (2004) and Mutambatsere (2007).

The total number of the products in which the triangular bloc has comparative advantage is fairly high amounting to 3345 product lines. This makes NAFTA one of the highest competitive regional trading blocs compared to some dotted around the world. The United States appears to benefit more than the other two partners as it has a very large number of products in which it has comparative advantage hence the protection offered by the regional bloc in shutting out other low cost producers benefit much more the United States of America theoretically. The protection measures secure markets for the United States theoretically in which it would have been facing stiff competition from very least cost producers such as China.

However, just like any other regional trading bloc, there are plus or minus 2000 products in which the three member group may not have a slight comparative advantage in hence may be replacing least cost producers. Further, the United States of America indices although in large number of products may not be fairly high compared to other low cost producer. Therefore Canada and Mexico are being deprived from an opportunity of scouting least cost producers as a result of protective measures of NAFTA. This then guarantees the United States of America markets in their countries even though the United States of America may not be the best least producer at all. There is however evidence that the countries in the triangular trade bloc are benefitting from trading amongst themselves. The high volume of trade amongst themselves shows that payments for such imports are in fact earnings of the region. This could not have been the case if the three members had imported such goods from outside NAFTA because the payments for such imports would not have remained in the region. 


\subsection{Analysis of Intra-Nafta Trade Performance}

Table 4 shows Canada's export to Mexico from 2007 to 2011.

Table 4. Canada's export to Mexico from 2007 to 2011 (values in US\$ thousands)

\begin{tabular}{ccccc}
\hline $\mathbf{2 0 0 7}$ & $\mathbf{2 0 0 8}$ & $\mathbf{2 0 0 9}$ & $\mathbf{2 0 1 0}$ & $\mathbf{2 0 1 1}$ \\
\hline 4626062 & 5517021 & 4220206 & 4865217 & 5529591
\end{tabular}

Source: Extracted from ITC's Trademap.

Taking 2007 as a base year Canada's export to Mexico under NAFTA grew by $19 \%$ in 2008 then fell by $-8.8 \%$ in 2009 before rising again by $5.2 \%$ in 2010. Canada's exports grew further in 2011 by $19.3 \%$. Table 5 shows Canada's exports to the United States from 2007 to 2011.

Table 5. Canada's exports to United States of America from 2007 to 2011 (values in US\$ thousands)

\begin{tabular}{ccccc}
\hline $\mathbf{2 0 0 7}$ & $\mathbf{2 0 0 8}$ & $\mathbf{2 0 0 9}$ & $\mathbf{2 0 1 0}$ & $\mathbf{2 0 1 1}$ \\
\hline 331601972 & 363782675 & 236480912 & 289418959 & 331737895
\end{tabular}

Source: Extracted from ITC 's Trademap.

In 2008, Canada's exports to the United States grew by $9.7 \%$ before shrinking by -28.7 in 2009 . The export also shrunk by $-12.7 \%$ in 2010 and then slightly picked up by $0.4 \%$ in 2011 . Table 6 shows Canada's export to the world from 2007 to 2011.

Table 6. Canada's exports to the world from 2007 to 2011 (values in US\$ thousands)

\begin{tabular}{ccccc}
\hline $\mathbf{2 0 0 7}$ & $\mathbf{2 0 0 8}$ & $\mathbf{2 0 0 9}$ & $\mathbf{2 0 1 0}$ & $\mathbf{2 0 1 1}$ \\
\hline 419881864 & 455632184 & 316176831 & 386679900 & 450396905 \\
\hline
\end{tabular}

Source: Extracted from ITC's Trademap.

Canada's exports to the world grew by $8.5 \%$ in 2008 then fell to $-24.7 \%$ in 2009 . Export fell again in 2010 by $-7.7 \%$ before picking up in 2011 by $7.3 \%$. Canada's exports to the world are much higher in absolute values than its exports to NAFTA. Canada's exports to the United States of America under NAFTA are the highest to a single country comparedto any other country in the world. In absolute value, Canada's exports to the NAFTA are very high despite them fluctuating. Canada's exports to the United States are about 66 times more than its exports to Mexico signifying that the United States of America is the largest trading partner of Canada than Mexico. It also signifies the strength of the United States of America's economy and growing import demand and its ability to pay for imports.

Table 7 shows Mexico's exports to the United States of America from 2007 to 2011.

Table 7. Mexico's exports to the United States from 2007 to 2011 (values in US\$ thousands)

\begin{tabular}{ccccc}
\hline $\mathbf{2 0 0 7}$ & $\mathbf{2 0 0 8}$ & $\mathbf{2 0 0 9}$ & $\mathbf{2 0 1 0}$ & $\mathbf{2 0 1 1}$ \\
\hline 223387835 & 233793948 & 185448619 & 238858912 & 274992000
\end{tabular}

Source: Extracted from Trademap.

In 2008, Mexico's exports to the United States of America grew by $4.7 \%$ and then fell by $-17 \%$ in 2009. In 2009, Mexico's exports to the United States grew by $6.9 \%$ in 2010 . There was a further growth of $23.1 \%$ in 2011 . Table 8 shows Mexico's exports to Canada from 2007 to 2011. 
Table 8. Mexico's exports to Canada from 2007 to 2011 (values in US\$ thousands)

\begin{tabular}{ccccc}
\hline $\mathbf{2 0 0 7}$ & $\mathbf{2 0 0 8}$ & $\mathbf{2 0 0 9}$ & $\mathbf{2 0 1 0}$ & $\mathbf{2 0 1 1}$ \\
\hline 6477823 & 7083682 & 8236476 & 10663920 & 10676125 \\
\hline
\end{tabular}

Source: Extracted from ITC's Trademap.

Mexico's exports to Canada grew by $9.4 \%$ in 2008 and then grew further by $27.1 \%$ in 2009 then soared to $64.6 \%$ in 2010. In 2011, Mexico's exports to Canada grew by 64.8\%. Mexico has experienced expansion in its exports to Canada. Canada suffered trade deficit in 2007 amounting to US\$1.9 billion then US\$1.6 billion in 2008 then the trade deficit worsened to US\$4 billion in 2009. In 2010 Canada suffered another trade deficit amounting to US $\$ 5.8$ billion while in 2011 it suffered a trade deficit of US\$5.1 billion. Table 9 shows Mexico's exports to the world from 2007 to 2011.

Table 9. Mexico's exports to the world from 2007 to 2011 (values in US\$ thousand)

\begin{tabular}{ccccc}
\hline $\mathbf{2 0 0 7}$ & $\mathbf{2 0 0 8}$ & $\mathbf{2 0 0 9}$ & $\mathbf{2 0 1 0}$ & $\mathbf{2 0 1 1}$ \\
\hline 271821215 & 291264809 & 229712337 & 298305075 & 349569049 \\
\hline
\end{tabular}

Source: Extracted from ITC's Trademap.

Mexico exports much more to the world than to NAFTA member states. Mexico's exports to the world grew by $7.2 \%$ in 2008 before falling by $-15.5 \%$ in 2009. In 2010, Mexico's exports to the world grew by $9.7 \%$ and then in 2011 they grew further by $28.6 \%$. While Mexico's exports to the world fell by $-15.5 \%$ in 2009 , its exports to Canada in the same year grew by $27.1 \%$ however; the exports to the United States of America fell by $-17 \%$ during the same period.

Table 10 shows United States of America's export to Canada from 2007 to 2011.

Table 10. United States of America exports to Canada from 2007 to 2011 (values in US\$ thousands)

\begin{tabular}{ccccc}
\hline $\mathbf{2 0 0 7}$ & $\mathbf{2 0 0 8}$ & $\mathbf{2 0 0 9}$ & $\mathbf{2 0 1 0}$ & $\mathbf{2 0 1 1}$ \\
\hline 248408864 & 260690167 & 204720827 & 248186864 & 280710218
\end{tabular}

Source: Extracted from ITC's Trademap.

The United States of America's exports to Canada grew by 4.9\% in 2008 then fell by $-17.6 \%$ in 2009 and then slightly fell by $-0.1 \%$ in 2010. In 2011, the United States of America's exports to Canada grew by $13 \%$. The United States suffered trade deficit to Canada amounting to US\$83.2 billion in 2007, US\$103.1 billion in 2008, US $\$ 31.8$ billion in 2009, US\$41.2 billion in 2010 and US $\$ 51$ billion in 2011. Canada suffered trade deficit to Mexico during the same period but appears to have gained ground of being a net exporter to the United States in a very big way than its losses to Mexico. Table 11 shows the United States of America's exports to Mexico from 2007 to 2011.

Table 11. United States of America exports to Mexico from 2007 to 2011 (values in US\$ thousand)

\begin{tabular}{ccccc}
\hline $\mathbf{2 0 0 7}$ & $\mathbf{2 0 0 8}$ & $\mathbf{2 0 0 9}$ & $\mathbf{2 0 1 0}$ & $\mathbf{2 0 1 1}$ \\
\hline 136620317 & 151624789 & 128997663 & 163320690 & 197543627
\end{tabular}

Source: Extracted from ITC's Trademap.

The United States of America's exports to Mexico grew by $11 \%$ in 2008 and then fell by $-5.6 \%$ in 2009. In 2010 exports grew by $19.5 \%$ and then soared by $44.6 \%$ in 2011 . The United States of America suffered again trade deficit to Mexico amounting to US\$86.8 billion in 2007, US\$82.2 billion in 2008, US\$56.5 billion in 2009, US\$75.5 billion in 2010 and US\$77.4 billion in 2011. Table 12 shows the United States of America's exports to the world from 2007 to 2011. 
Table 11. United States of America exports to the world from 2007 to 2011 (values in US\$ thousands)

\begin{tabular}{cccccc}
\hline \multicolumn{2}{c}{2007} & $\mathbf{2 0 0 8}$ & $\mathbf{2 0 0 9}$ & $\mathbf{2 0 1 0}$ & $\mathbf{2 0 1 1}$ \\
\hline 1162538150 & 1299898877 & 1056712078 & 1277109162 & 1479730169
\end{tabular}

Source: Extracted from ITC's Trademap.

The United States of America exports much more to the world than it does to NAFTA members. Its exports run in trillion dollars. In 2008, the United States exports to the world grew by $11.8 \%$ and then in 2009 fell by $-9.1 \%$. In 2010, they grew by $9.9 \%$ and then in 2011 grew further by $27.3 \%$.

\subsection{Analysis of Comparative Advantage and Trade Perfomance in Respect of Intra-Regional Trade}

The United States of America is the most competitive country in the triangular trade arrangement (NAFTA). It has comparative advantage in 1791 products. It is followed by Canada with 814 products then the least being Mexico with 749 products. The United States of America by virtue of having a large number of products in which it has comparative advantage in is expected to benefit much more than Canada and Mexico when protection measures of NAFTA are taken into account by virtue of shutting out low cost producers worldwide in favour of countries such as the United States of America within NAFTA. However, trade performance indicates that in fact it is the least competitive. Mexico, which is benefitting much more than the United States of America and Canada. Mexico has favourable trade balances with the United States of America and Canada in spite of having fewer products in which it has comparative advantage. Canada has also a favourable trade balance with the United States in spite of it having fewer products in which it has comparative advantage than the latter. Interestingly, the United States of America which has the largest number of products in which it has comparative advantage has unfavourable trade balances.

\section{Conclusions and Recommendations}

The United States has least degree of specialization in the products it has comparative advantage. Canada and Mexico demonstrates high degree of specialization in the products they have comparative advantage in. NAFTA member states trade much more outside the bloc than within intra-NAFTA although intra-NAFTA trade is also very substantial. In intra-regional trade context having comparative advantage does not lead to necessarily enjoying surpluses in trade. Therefore a weak country may benefit in intra-regional trade than strong countries. Mexico is the net exporter in NAFTA while the United States of America is the net importer under this trade arrangement. NAFTA trade performance has been fluctuating but the gains from the agreement are visible. It is recommended that the United States of America takes steps to narrow or wipe off trade deficits with both Canada and Mexico and use its comparative advantage by increasing exports by focusing on promotion of the products in which it has comparative advantage.

\section{References}

Balance, R. H., Forstner, H., \& Murray, T. (1987). Consistency Tests of Alternative Measures of Comparative Advantage. Review of Economics and Statistics, 69,157-161. http://dx.doi.org/10.2307/1937915

Balassa, B. (1965). Trade Liberalisation and Revealed Comparative Advantage. Newhaven: Yale University, Economic Growth Centre.

Bebek, U. G. (2011). Monotonicity of Additive Indices of Revealed Comparative Advantage. Economics Bulletin, 31(2), 1894-1901.

Bender, S., \& Li, K. (2002). The Changing Trade and Revealed Comparative Advantage of Asian and Latin American Manufacture Exports. Yale University, Economic Growth Center. Center Discussion paper No.843.

Chow, P. C. Y. (1990). The Revealed Comparative Advantage of the East Asian NICs. The International Trade Journal, 5(2), 235-262. http://dx.doi.org/10.1080/08853909008523715

Claiming Human Rights. (2012). Regional Economic Integration. Retrieved July 30, 2012, from www.claiminghumanrights.org/African/recs.htm

Deardorff, A. V. (2010). Thoughts on Revealed Comparative Advantage. OECD Global Forum on Trade Chengdu, China, October 14.

Donges, J. B. (1982). The Second Enlargement of the European Community Requirements and Challenges for Policy Reform. JCB Mohr Tubingen. 
European Union. (2010). Europe and you: A Snapshot of EU Achievements. Retrieved July 30, 2012, from www.ec.europa.eu/publications

FAO. (2012). Economic Aspects of Regional Integration. Retrieved July 30, 2012, from www.fao.org/docrep/004/y4793e/y4793eas.htm

Ferto, I., \& Hubbard, L. J. (2000). Revealed Comparative Advantage and Comparative and Competitiveness in Hungarian Agri-Food Sectors. Institute of Economics Hungarian Academy of Sciences, New Series 2002/8

Ford, A. (2012). A brief history of NAFTA. Retrieved July 7, 2012, from www.time.com/time/nation/article/0,8599,1868997,00.html

Global Economics. (2012). Free Trade Area. Retrieved July 29, 2012, from www.globaleconomicsgame.com/freetradeareas.htm

Hansen, J. M., \& Meyers, W. H. (2012). NAFTA and Domestic Policy Impact. US View. Retrived July 30, 2012, from $\mathrm{http} / / /$ agrinet.tamu.edu/trade/papers/naftajb2pdf

Institute for International Economics. (2012). Conclusions and Recommendations. Retrieved July 30, 2012, from www.plie.com/publications/chapters_preview/72/11i1e2024,pdf

ITC. (2012). Trade Statistics. Retrieved June 1, 2012, from www.trademap.org

Karakaya, E., \& Ozgen, F. G. (2002). Economic Feasibility of Turkey's Economic Integration with the EU: Prespective from Trade Creation and Trade Diversion. A Paper Presented at the METU VI, International Conference in Economics, Ankara, September 11-14.

Khatibi, A. (2008). Kazakhstan's Revealed Comparative Advantage Vis-à-vis the EU-27. ECIPE Working Paper no. $03 / 2008$

Krugell, W., \& Matthee, M. (2009). Measuring the Export Capability of South African Regions. Development Southern Africa, 26(3), 459-476. http://dx.doi.org/10.1080/03768350903086838

Lutz, J. M. (1987). Shifting Comparative Advantage. The NICs and the Development Countries. The International Trade Journal, 5(2), 339-358. http://dx.doi.org/10.1080/08853908708523623

Mirzaei, F., Yazdani, S., \& Gharahdaghi, A. A. (2004). Competitiveness of the Irania Egg Industry in the Middle East Region. Animal Science Research Institute. Retrieved July 30, 2012, from $\mathrm{ftp} / /$ ttp.fao.org/upload/-agrippa/672_endoc

Mutambatsere, E. (2007). Competiveness and Revealed Comparative Advantage in the SADC Maize Industry. AAAE Conference Proceedings, 57-62.

Mzumara, M. (2006). The Theory of Money and Banking in Modern Times. Mustang: Tate Publishing LCC.

Mzumara, M. (2011a). Was Zimbabwe Competitive in International Trade 200 - 2009? International Journal of Economics and Research, 2(6), 200-221.

Mzumara, M. (2011b). Mozambique from Marxist - Leninist to Capitalism: Has the Country Performed Well Economically? International Journal of Business Management and Economic Research, 2(6), 359-370.

Mzumara, M. (2012). Botswana a Mono-Diamond Economy or not. International Journal of Management Sciences and Business Research, 1(5), 21-46.

NAFTA. (2012). North American Free Trade Agreement. Retrieved July 7, 2012, from www.nafta-sec-alena-org/en/view

OAS-SEDI-DEDIT. (2012). North American Free Trade Agreement. Retrieved July 7, 2012, from www.sice.oas.org/trade/nafta/chap-(1).asp

Odhiambo, S. (2010). Assessing the Impact of the Principle of Asymmetry on Export Performance and Compatitiveness in EAC Customs Union: A Case of Uganda. A thesis submitted in Partial Fulfillment of the Requirements for the Degree of MSc International Trade Policy and Trade Law, Schoool of Economics and Management, Lund University.

Richardson, D. J., \& Zhang, C. (1999). Revealing Comparative Advantage: Chaotic or Coherent Pattern Across Time and Sector and the US Trading Partner? National Bureau of Economic Research, Working Paper 7212.

Serin, V., \& Civan, A. (2008). Revealed Comparative Advantage and Competitiveness: A Case Study for Turkey towards the EU. Journal of Economic and Social Research, 10(2), 25-41. 
Shinyakwa, I., \& Othieno, L. (2011). Uganda's Revealed Comparative Advantage: The Evidence with EAC and China. Retrieved July 30, 2012, from http//www.eprc.or.ug/pdf_files/ugcomparativeadvantage.pdf

USDA. (2012). North American Free Trade Agreement. Retrieved July 7, 2012, from www.fas.usda.gov/cp/policy/NAFTA/nafta.asp

Utkulu, U., \& Seymen, D. (2004). Revealed Comparative Advantage and Competiveness: Evidence for Turkey Vis-a - Vis the EU/15. Paper Presented at the European Trade Study Group $6^{\text {th }}$ Annual Conference, Nottingham, September.

Vollrath, T. L. (1991). A Theoretical Evaluation of Alternative Trade Intensity Measures of Revealed Comparative Advantage. Weltwirtschaftliches Archiv, 130, 265-279. http://dx.doi.org/10.1007/BF02707986

Widgren, M. (2005). Revealed Comparative Advantage in the Market. Turku School of Economics, The Research Institute of Finish Economy (ETLA), CEPR and CESifo.

World Bank. (2012). Regional Integration: Concepts, Advantage, Disadvantages and Lessons of Experience. Retrieved July 30, 2012, from www.siteresource.worldbank.org

Wu, H. L., \& Chen, C. H. (2004). Changes in the Foreign Market Competitiveness of East Asian Export. Journal of Contemporary Asia, 34(4), 505-522. http://dx.doi.org/10.1080/00472330480000241

Yeats, A. (1997). Does Mercosur's Trade Performance Raise Concerns about the Effects of Regional Trade Arrangement? World Bank Policy Research Working Paper 1729.

Yue, C. (2001). Comparative Advantage, Exchange Rate and Exports in China. Paper prepared for the International Conference on Chinese economy, CERDI, France.

Zahniser, S., \& Crago, Z. (2009). Building on Free Trade. Retrieved July 7, 2012, from www.ers.usda.gov

\section{Appendix A}

Comparison between USA exports and world exports in top products the USA has comparative advantage in (US\$ thousand)

\begin{tabular}{|c|c|c|c|c|c|c|c|c|}
\hline Product & $\begin{array}{c}2007 \text { USA } \\
\text { exports }\end{array}$ & $\begin{array}{c}2007 \\
\text { World } \\
\text { exports }\end{array}$ & $\begin{array}{c}2008 \\
\text { USA } \\
\text { exports }\end{array}$ & $\begin{array}{c}2008 \\
\text { World } \\
\text { exports }\end{array}$ & $\begin{array}{c}2009 \\
\text { USA } \\
\text { exports }\end{array}$ & $\begin{array}{l}2009 \text { World } \\
\text { exports }\end{array}$ & $\begin{array}{c}2010 \\
\text { USA } \\
\text { exports }\end{array}$ & $\begin{array}{c}2010 \\
\text { World } \\
\text { exports }\end{array}$ \\
\hline Insulin & 167987 & 183507 & 161127 & 120868 & 161501 & 178761 & 128783 & 150304 \\
\hline Artillery weapon & 48120 & 62379 & 67976 & 79107 & 44137 & 44337 & 72312 & 74664 \\
\hline Brewing dregs & 391912 & 485284 & 078688 & 1147640 & 965733 & 1177523 & 1623216 & 1818657 \\
\hline $\begin{array}{l}\text { Air combat } \\
\text { simulators }\end{array}$ & 62983 & 82652 & 105780 & 159399 & 153187 & 173296 & 108181 & 123903 \\
\hline Flour & 409582 & 500360 & 744440 & 875872 & 552799 & 766526 & 744523 & 975901 \\
\hline Almonds & 242532 & 321966 & 335466 & 440053 & 431156 & 582049 & 528902 & 577908 \\
\hline Drawing instrument & 697052 & 912733 & 591293 & 817489 & 559029 & 739307 & 553575 & 740877 \\
\hline 1(1,3-Benzodioxd-5y & 120 & 313 & 0 & 634 & 77 & 178 & 271 & 322 \\
\hline Photo films & 46031 & 64058 & 43395 & 55792 & 26257 & 35733 & 22755 & 35403 \\
\hline Paper & 92813 & 128907 & 100210 & 129915 & 72711 & 104494 & 64159 & 95599 \\
\hline Chemical wood pulp & 4243 & 5840 & 7504 & 9083 & 989 & 1646 & 1995 & 3094 \\
\hline Sorghum & 1051676 & 1434390 & 1256085 & 1711549 & 652624 & 903460 & 743997 & 1168496 \\
\hline Film colour $<16 \mathrm{~mm}$ & 2752 & 4796 & 2577 & 4283 & 1318 & 1752 & 2068 & 2544 \\
\hline Almonds fresh & 11525307 & 2323885 & 1478124 & 2231930 & 1424530 & 2127921 & 1807378 & 2534872 \\
\hline Disodium tetraborate & 129355 & 206582 & 176097 & 262850 & 164740 & 245611 & 190126 & 293081 \\
\hline 271311 & $\begin{array}{l}\text { Petroleum } \\
\text { coke }\end{array}$ & 1075827 & 2155368 & 1928917 & 2939057 & 109351585964 & 2337267 & 3181650 \\
\hline Veneer & 13494 & 49433 & 92121 & 125266 & 47335 & 635507 & 47231 & 58057 \\
\hline
\end{tabular}

Source: Extracted from ITC 's Trademap. 


\section{Appendix B}

Comparison between Canada exports and world exports in top products Canada has comparative advantage in (US\$ thousand)

\begin{tabular}{|c|c|c|c|c|c|c|c|c|}
\hline Product & $\begin{array}{c}2007 \\
\text { Canada } \\
\text { exports }\end{array}$ & $\begin{array}{c}2007 \\
\text { World } \\
\text { exports }\end{array}$ & $\begin{array}{c}2008 \\
\text { Canada } \\
\text { exports }\end{array}$ & $\begin{array}{c}2008 \\
\text { World } \\
\text { exports }\end{array}$ & $\begin{array}{c}2009 \\
\text { Canada } \\
\text { exports }\end{array}$ & $\begin{array}{c}2009 \\
\text { World } \\
\text { exports }\end{array}$ & $\begin{array}{c}2010 \\
\text { Canada } \\
\text { exports }\end{array}$ & $\begin{array}{c}2010 \\
\text { World } \\
\text { exports }\end{array}$ \\
\hline Maple sugar & 203013 & 227391 & 220652 & 253470 & 222043 & 262513 & 224693 & 262301 \\
\hline $\begin{array}{l}\text { Shingles of } \\
\text { wood }\end{array}$ & 313665 & 365625 & 245124 & 288623 & 1555110 & 187156 & 160079 & 191067 \\
\hline Canary seed & 87863 & 106763 & 126899 & 154811 & 78977 & 98993 & 100387 & 129675 \\
\hline Lobster frozen & 332671 & 459856 & 370236 & 479001 & 272745 & 359253 & 421303 & 516160 \\
\hline $\begin{array}{l}\text { Lobster } \\
\text { prepared }\end{array}$ & 116883 & 153916 & 150176 & 181632 & 99815 & 141444 & 161080 & 208026 \\
\hline $\begin{array}{l}\text { Sodium } \\
\text { chlorate }\end{array}$ & 262967 & 390727 & 324237 & 448053 & 367105 & 420763 & 343015 & 451010 \\
\hline $\begin{array}{l}\text { Semi-chemical } \\
\text { wood pulp }\end{array}$ & 1052860 & 1459761 & 1147138 & 1715040 & 885020 & 1259464 & 1389175 & 2068664 \\
\hline $\begin{array}{l}\text { Ground flying } \\
\text { trainee }\end{array}$ & 489509 & 805954 & 717116 & 1179402 & 433095 & 531968 & 478663 & 642273 \\
\hline Herrings & 21772 & 33685 & 25833 & 42518 & 26480 & 38536 & 28184 & 40230 \\
\hline $\begin{array}{l}\text { Turbo-prop } \\
\text { engines }\end{array}$ & 627340 & 1047313 & 724025 & 1234207 & 660101 & 978638 & 622130 & 935306 \\
\hline Diamonds & 1133488 & 1994010 & 1773885 & 2776975 & 1096571 & 1954626 & 1855922 & 2951015 \\
\hline Oats & 400293 & 626468 & 542238 & 900824 & 329391 & 555780 & 326466 & 570809 \\
\hline $\begin{array}{l}\text { Zirconium } \\
\text { waste }\end{array}$ & 6455 & 11298 & 8314 & 17799 & 6875 & 10746 & 8641 & 13741 \\
\hline Lentils dried & 4777700 & 901970 & 802475 & 1348253 & 918504 & 1505188 & 981197 & 1667610 \\
\hline Heavy water & 14543 & 21634 & 13082 & 33764 & 9985 & 18183 & 12528 & 20184 \\
\hline Sulphur & 45196 & 104425 & 383310 & 540374 & 49008 & 97511 & 120389 & 211868 \\
\hline Cereal groats & 53017 & 112322 & 78329 & 145671 & 67182 & 122913 & 63564 & 116913 \\
\hline Leucite & 65889 & 1277070 & 57286 & 125966 & 56603 & 111676 & 81944 & 144065 \\
\hline $\begin{array}{l}\text { Meat \& edible } \\
\text { meat offal of } \\
\text { primates }\end{array}$ & 0 & 2329 & 0 & 1315 & 4 & 606 & 359 & 532 \\
\hline
\end{tabular}

Source: Extracted from ITC 's Trademap. 


\section{Appendix C}

Comparison between Mexico exports and world exports in top products the USA has comparative advantage in (US\$ thousand)

\begin{tabular}{|c|c|c|c|c|c|c|c|c|}
\hline Product & $\begin{array}{c}2007 \\
\text { Mexico } \\
\text { exports }\end{array}$ & $\begin{array}{c}2007 \\
\text { World } \\
\text { exports }\end{array}$ & $\begin{array}{c}2008 \\
\text { Mexico } \\
\text { exports }\end{array}$ & $\begin{array}{c}2008 \\
\text { World } \\
\text { exports }\end{array}$ & $\begin{array}{c}2009 \\
\text { Mexico } \\
\text { exports }\end{array}$ & $\begin{array}{c}2009 \\
\text { World } \\
\text { exports }\end{array}$ & $\begin{array}{c}2010 \\
\text { Mexico } \\
\text { exports }\end{array}$ & $\begin{array}{c}2010 \\
\text { World } \\
\text { exports }\end{array}$ \\
\hline $\begin{array}{l}\text { Railway cars, } \\
\text { closed or open }\end{array}$ & 311399 & 528935 & 268062 & 575568 & 103791 & 229376 & 155803 & 256924 \\
\hline $\begin{array}{l}\text { Antimony } \\
\text { waste and } \\
\text { scrap }\end{array}$ & 1721 & 3497 & 1128 & 3272 & 1128 & 2748 & 1061 & 7056 \\
\hline $\begin{array}{l}\text { Avocados, } \\
\text { fresh or dried }\end{array}$ & 601177 & 1311726 & 577193 & 1335435 & 645412 & 1507150 & 594010 & 1421928 \\
\hline Papaws, fresh & 53780 & 184528 & 53373 & 183354 & 74966 & 199157 & 69516 & 2000213 \\
\hline $\begin{array}{l}\text { Cameras for } \\
35 \mathrm{~mm} \text { roll } \\
\text { films }\end{array}$ & 153176 & 528572 & 94969 & 279743 & 62164 & 190708 & 43211 & 138019 \\
\hline Bluefin tunas & 6824 & 140177 & 14374 & 87176 & 7604 & 13947 & 10317 & 21786 \\
\hline $\begin{array}{l}\text { Photo film in } \\
\text { rolls width } \\
16-35 \mathrm{~mm} \\
<30 \mathrm{~m} \text { long }\end{array}$ & 7894 & 24454 & 7318 & 217876 & 4895 & 17879 & 4390 & 16152 \\
\hline $\begin{array}{l}\text { Alcoholic } \\
\text { liqueurs }\end{array}$ & 740012 & 2405086 & 709021 & 2514562 & 627119 & 2264469 & 760145 & 2485423 \\
\hline $\begin{array}{l}\text { Strontium } \\
\text { carbonate }\end{array}$ & 22796 & 156153 & 21284 & 174858 & 11657 & 25111 & 11692 & 31446 \\
\hline $\begin{array}{l}\text { Film colour } \\
\text { photo rolls } \\
\text { width } 16-35 \mathrm{~m} \\
<30 \mathrm{~m} \text { long }\end{array}$ & 189847 & 782870 & 121543 & 447991 & 68806 & 223813 & 52922 & 209190 \\
\hline $\begin{array}{l}\text { Spark ignition } \\
\text { engine trucks } \\
\text { weighing }<5 \\
\text { tonnes }\end{array}$ & 4291822 & 24793106 & 4428406 & 18985908 & 4715415 & 15083418 & 6858352 & 20286425 \\
\hline $\begin{array}{l}\text { Hydrogen } \\
\text { fluoride }\end{array}$ & 119210 & 444674 & 114401 & 559489 & 113633 & 406139 & 142863 & 599535 \\
\hline $\begin{array}{c}\text { Ceramic } \\
\text { bathroom } \\
\text { kitchen } \\
\text { sanitary items }\end{array}$ & 394385 & 1894607 & 399543 & 1828180 & 344079 & 1336163 & 395844 & 1454349 \\
\hline $\begin{array}{l}\text { Water melons, } \\
\text { fresh }\end{array}$ & 190480 & 908790 & 234833 & 1079324 & 287681 & 1035631 & 234833 & 1166084 \\
\hline $\begin{array}{l}\text { Fluospar } \\
<9.7 \% \text { calcium } \\
\text { fluoride }\end{array}$ & 43403 & 212837 & 59155 & 343305 & 59657 & 203770 & 68164 & 292851 \\
\hline $\begin{array}{c}\text { Acetic } \\
\text { anhydride }\end{array}$ & 61711 & 359599 & 71638 & 430282 & 93957 & 334208 & 91075 & 377744 \\
\hline Copper alloy & 72213 & 6821222 & 86815 & 680341 & 128835 & 511998 & 260832 & 777646 \\
\hline Alums & 2656 & 18135 & 4079 & 20246 & 4167 & 20536 & 4762 & 19830 \\
\hline $\begin{array}{l}\text { Brussels } \\
\text { sprouts }\end{array}$ & 29703 & 115522 & 34360 & 123923 & 20605 & 96054 & 23450 & 103662 \\
\hline Asparagus & 116553 & 709486 & 101582 & 738428 & 146209 & 761302 & 217413 & 901848 \\
\hline
\end{tabular}

Source: Extracted from ITC 's Trademap. 